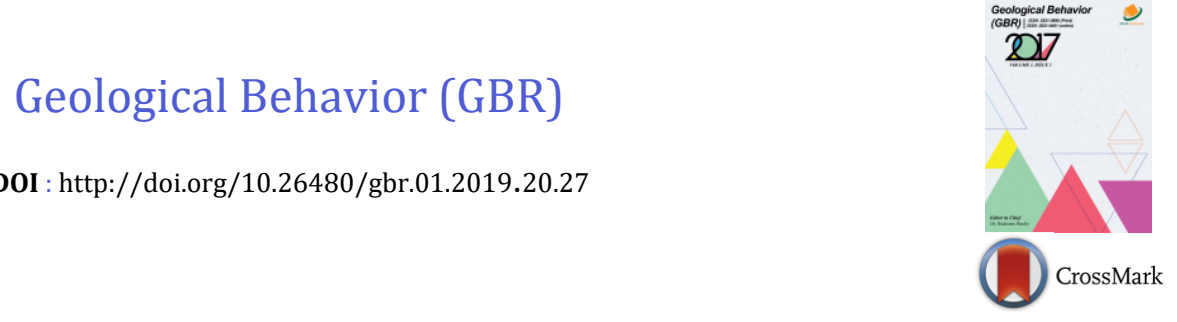

\title{
RESEARCH ARTICLE \\ MIDDLE MIOCENE WAVE INFLUENCED TIDAL DOMINATED LAMBIR FORMATION, MIRI, SARAWAK: CASE STUDY IN TUSAN BEACH AND LAMBIR HILL
}

\author{
Muhd Nur Ismail Abdul Rahman* and Sanudin Tahir \\ Fakulti Sains dan Sumber Alam, Universiti Malaysia Sabah \\ *Corresponding Author Email: ismailar.rakiti89@gmail.com
}

This is an open access article distributed under the Creative Commons Attribution License, which permits unrestricted use, distribution, and reproduction in any medium, provided the original work is properly cited.

\section{ARTICLE DETAILS}

\section{Article History:}

Received 1 January 2019

Accepted 19 February 2019

Available online 21 February 2019

\section{ABSTRACT}

The Middle Miocene sedimentary faciess classified as the Lambir Formation at Tusan Beach and Lambir Hill is revealed as tide dominated with exposed minor wave regimes association. Evidence of wave dominated facies is displayed mostly on shoreline deposits, such as planar cross stratified (PcS), swaley cross stratified (ScS), swaley-Hummocky cross stratified (SHcS) and hummocky cross stratified (HcS). The facies analysis reveals four facies associations, namely; foreshore facies association, upper shoreface, middle shoreface and lower shoreface. Whereas, tide dominated regime resulted three major facies association: tidal sand bar (TSB) facies association, tidal sand flat facies association (TSF) and subtidal mud flat (SMF). TSB facies association was developed from tide influenced shoreline that represented by herringbone cross stratified sandstone bed. The occurrence of herringbone cross stratified and other tidally structures within same facies explain that the current activities are in reversal process (flood and ebb). TSF and SMF facies associations, are widely distributed in the central Miri region including part of Lambir Hill and the Nakat River area. Wide exposure of frequent heterolitic beds, suggest that the Lambir Formation was deposited within the tidal flat environment.

\section{KEYWORDS}

Wave dominated facies, tide dominated facies, shoreface, heterolitic

\section{INTRODUCTION}

Shallow marine sediments are widely distributed along North Sarawak, mainly from Bintulu to Miri areas. This research covers an area from Tusan Beach in the North West and Lambir Hills in the south of Miri town. The

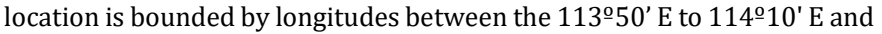
between the latitudes of $4{ }^{\circ} 10^{\prime} \mathrm{N}$ to $4^{\circ} 20^{\prime} \mathrm{N}$ (Figure 1). The area is known as moderate topography. The highest peak at Lambir Hills is about 405 meter height. The geological features, sedimentary structures and geometrical behaviour are indicators to describe shallow marine outcrops. This area consists of the Middle Miocene rock unit [1,2].

According to sedimentation record, as stated by a researcher, numerous sedimentary structures are displayed as tide-dominated regime at Tusan Beach and Nakat River areas. The evidence of tidally sedimentary structure, like heterolithic and herringbone structures are most common in the study area. Heterolithic rock is divided into three sub facies, namely (i) flaser bed, (ii) wavy bed and (iii) lenticular bed. This study was elaborated more by a researcher through sedimentological and ichnology aspects. The study found, tidal structure most dominant exposed in the study area.

Apart from that, wave dominated structure also exposed along the Lambir Hill and Tusan Beach areas. However, it is not too extensively distributed. Evidence of hummocky-swaley cross bed in a few outcrops at Tusan Beach and Lambir Hill reveal significant data for wave dominated regime. According to this condition, a researcher suggested that tidally setting could be observed within time range between strong tidal current and fair weather wave base [3].

This study discusses tidal generated facies and wave dominated regime throughout this area. In addition, a sedimentological data is integrated with stratigraphic aspect to develop appropriate model on tidally distribution facies. Once sedimentology aspect has been recognised, tidal model shall be established and proposed towards the better understanding about tidal influenced regime in the study area.

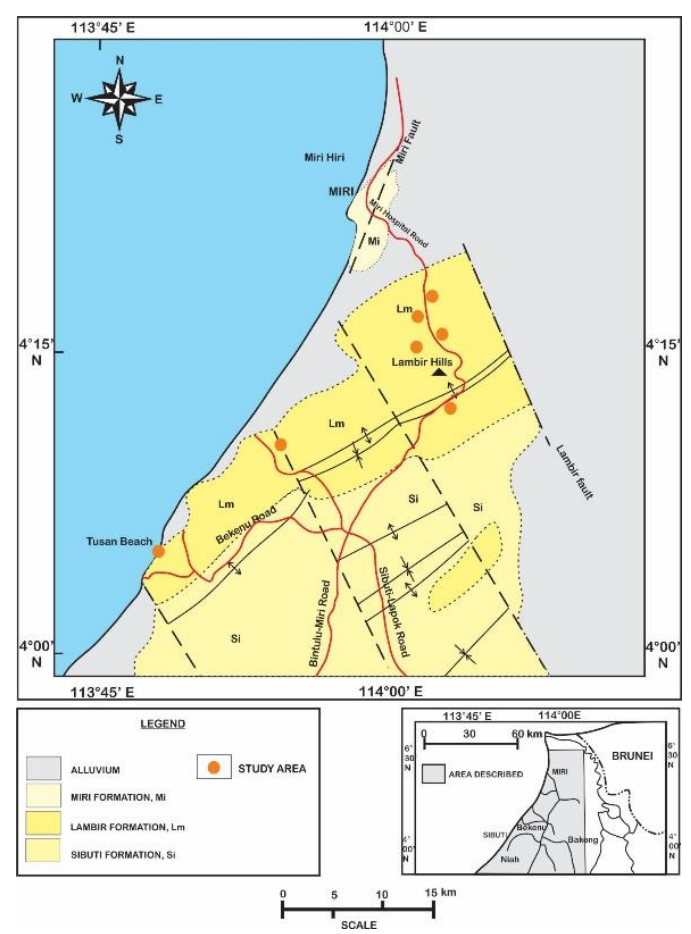

Figure 1: Map showing distribution of the Lambir Formation and the 
location of study area, adaptation from Banda and Honza (1997)

\section{GENERAL GEOLOGY AND STRATIGRAPHY}

In geological map and stratigraphic column, the Lambir Formation is positioned as interfingering with the Miri Formation. This study area is basically dominated by the Lambir Formation (Figure 1). General aspect of the Lambir Formation according to a researcher, stated that the distribution of the rock unit is an alternation of sandstone and mudstone of a similar type to that of the Belait Formation, but with a distinctive calcareous admixture (limestone, calcareous shale) which however, may be locally absent. A previous researcher explained that the lithofacies of the Lambir Formation represented by calcareous and non-calcareous units [4]. He stated that, a calcareous concretion, sandstone and shale present in most outcrops officially belongs to the Lambir Formation. A documented study by Lim Chun Hui and Mohd Shafeea Leman (1994) about the Lambir Formation in Ulu Bok Syncline recognizes a lithologic unit in the Lambir Formation consisting of interbedded sandstone and shale. According to Lim Chun Hui and Shafeea Leman (1994), evidence by macro and micro fossils present, the Lambir Formation generally was deposited in area ranged from littoral to inner neritic.

According to Banda and Honza (1997), this formation consists of sandstone interbedded with shale. It was mainly sandy deposit rather than mud. A researcher stated that the rock unit of the Lambir Formation composed of thick-bedded sandstones overlay medium dark-grey mudstone and calcareous mudstone (belong to Sibuti or Setap Shale Formation) [5]. The calcareous mudstone contains foraminifera and crabs fossils. Several facies were recognized by a researcher such as hummocky cross-bedding and planar cross-bedding. He explains a different thing about shallow marine environment of the Lambir Formation regarding on abundance of gypsum.

A previous researcher suggested that the Lambir Formation was interpreted as predominantly prograding deposits of fluvio-marine and shallow marine silliciclastics where the Lambir sequence was believed to have a thickness about 3000 meter in the SW Lambir area and the offshore Baram delta. Moreover, they also stated that in the Lambir Formation, some conglomerate clasts and milky coarse quartzes exposed in a few outcrops in Lambir, whereas fine-grained sandstones dominate the Brunei outcrops.

\section{METHODOLOGY}

Seven facies including three sub facies (tidal facies) were recorded from the field observation and then being analysed by using vertical litholog analysis. From that data, they are grouped into two major depositional regimes, namely wave and tidal dominated regimes. Sedimentology aspect observed is based on five parameters of facies analysis; however, the facies is to be characterised by using sedimentary structures, due to its closely related to their environment of deposition.

\section{RESULT: FACIES ANALYSIS}

\subsection{Facies Analysis}

Two major lithofacies have recently been recognized on the most basic textures and sedimentary structures in the bed from the litholog analysis (Table 1). Two different processes of regimes are proposed regarding on various behaviour of environment activities. First one is wave dominated regime and second is tidal dominated regime (most major facies). Wave dominated regime comprises of four facies, namely planar cross stratified sandstone bed (PcS), swaley cross stratified sandstone bed (ScS), swaleyhummocky cross stratified sandstone bed $(\mathrm{SHcS})$ and hummocky crossstratified sandstone bed ( $\mathrm{HcS})$. Whereas, tidal dominated regime consists of herringbone bedded (Hrr) and Heterolithic bed (He) facies.

PcS facies consists of thick and amalgamated bed that ranges in thickness from $60 \mathrm{~cm}$ to 2 meters. The ScS facies usually thick and amalgamated, is related to high energy process during storm event. Individual bed displays less scour, good sorting grains of medium to coarse grain size. In every single bed, it shows coarsening upward sequence. The SHcS facies shows that, the swalley cross stratified lied at the upper bed position and then continuously repeated by medium scale of hummocky cross stratified in lower bed position. Apart, facies HcS is identified as sandstone interbedded with mudstone, poor to moderately sorted grain size with various pattern of sandstone bedding (scour resembling swales bed, disconnected bed and non-homogeneous bed). Most of the patterns generally resemble naturally occurring phenomenon during storm.

In a tidally dominated regime two major facies have recently been recognized on the most basic of sedimentary textures and structures (Table 1). They are Herringbone bedded facies (Hrr) (mostly obscure in this research) and heterolithic facies (He). The herringbone bedded facies is occasionally found structure in Hrr facies. The bedding thickness ranges from 6 to $10 \mathrm{~cm}$ thick. The heterolithic facies $(\mathrm{He})$ can be divided into three sub-facies, namely flaser ( $\mathrm{Hf}$ ), wavy ( $\mathrm{Hw}$ ) and lenticular bedding ( $\mathrm{Hl})$. Most of the structural patterns are based on percentage of sand and mud. The $\mathrm{Hl}$ and $\mathrm{Hw}$ sub-facies are distributed widely in the study study area from Tusan Beach to Bakam Road, meanwhile Hf fasies only found at Tusan beach.

Table 1: Facies attribute to wave and tide dominated environment.

\begin{tabular}{|c|c|c|c|l|}
\hline $\begin{array}{c}\text { Facies code/ } \\
\text { Aspect }\end{array}$ & \multicolumn{1}{|c|}{ Locality } & $\begin{array}{c}\text { Lithology/grain } \\
\text { size }\end{array}$ & \multicolumn{1}{|c|}{ Sedimentary structure } & \multicolumn{1}{|c|}{ Interpretation of Environment } \\
\hline PcS & Beraya, Lambir Hill & coarse & Planar cross stratified sandstone & $\begin{array}{l}\text { - High energy transportation current. } \\
\text { - Foreshore }\end{array}$ \\
\hline ScS & Tusan Beach & Medium-coarse & Swaley cross stratified & $\begin{array}{l}\text { - High energy of storm occurs during deposition. } \\
\text { - Upper shoreface }\end{array}$ \\
\hline SHcS & Lambir Hill & Fine-medium & $\begin{array}{l}\text { Swaley cross stratified and } \\
\text { Hummocky cross stratified }\end{array}$ & $\begin{array}{l}\text { - Due to density current suspension after deposition by } \\
\text { continuous storm wave is subjected to the bottom of sediment. } \\
\text { - Middle shoreface }\end{array}$ \\
\hline HcS & Tusan Beach & Fine & Hummocky cross stratified & $\begin{array}{l}\text { - Decrease of wave energy in a lower shoreface environment } \\
\text { - Due to storm wave and occurs in the transition zone of fair } \\
\text { weather wave base and storm wave base }\end{array}$ \\
\hline Md & Lambir Hill, Sg. Nakat & Clay & Mud laminae & $\begin{array}{l}\text { - Deceleration of current energy because of the area is } \\
\text { protected by barrier sand }\end{array}$ \\
\hline Hrr & Tusan Beach & Silt-fine & Herringbone cross stratified & $\begin{array}{l}\text { - Produced by strong wave during different flow of tide } \\
\text { - Tidal Sand bar deposit }\end{array}$ \\
\hline
\end{tabular}




\subsection{Facies Association}

\subsubsection{Wave Dominated Regime}

4.2.1.1 Facies Association 1 (FA 1): Foreshore

\section{(1) Description}

This facies association 1 (FA 1) consists of white, thick and amalgamated sandstone bed with an individual bed thickness ranges from $50 \mathrm{~cm}$ to 1 meter (Photo 1 (a)). The individual sandstone bed exhibited planar cross stratified sandstone bed $(\mathrm{PcS})$ and obscure parallel laminae (Photo 1 (b) and (c)). Exposure of this facies is common in Miri, like Tusan Beach, Beraya, Airport Road and Miri Hill with equivalent features and geometry. The best exposure of this FA 1 is at Lambir Hill. In average, major outcrops measured is about 40 meters vertically and 300 meters laterally (Figure 2 (c)). Furthermore, the sequence displays coarsening upward texture with good sorting. The sandstone bed is sharp contact with the underlying laminated mudstone bed.

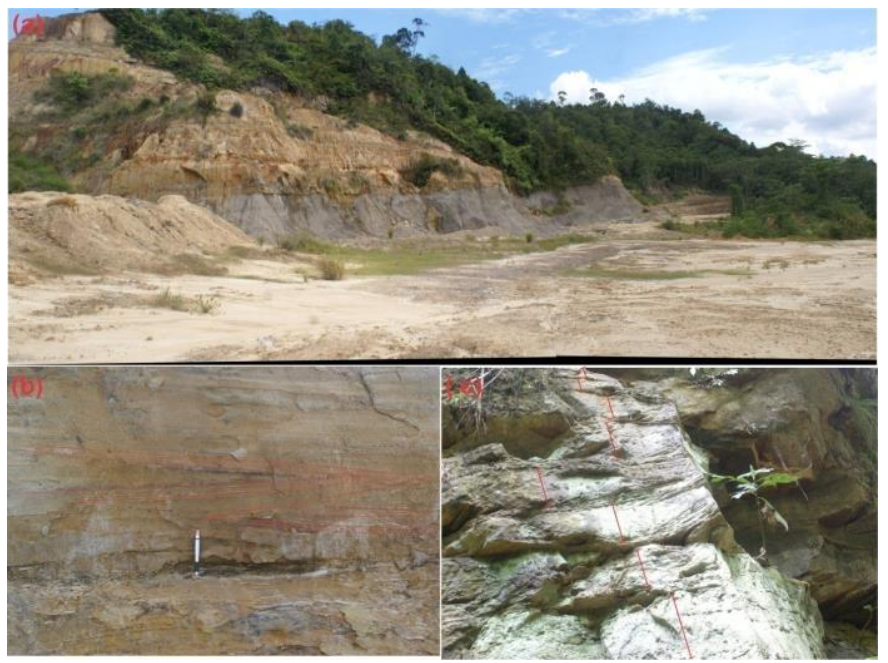

Photo 1: (a) Section of Lambir Hill outcrop, the planar cross stratified sandstone interbedded with lagoon mud deposit. (b) Co-set of planar cross stratification within thick sandstone bed. (c) Cycle of deposition representing by series of planar cross stratified (PcS) at Lambir Hill Forest Reserve

\section{(2) Interpretation}

Large sediment supply during deposition and high intense of storm accumulated series of sandstone bed without intermittent mud deposit. This is due to intermittent rapid forward and backward flow energy on the foreshore area of a shoreline setting. The series of planar cross bedded structures are not straight pattern due to high energy current during storm event. The thick and amalgamated sandstone bed may be occurred from sufficient amount of sediment supply during storm event. Besides, coarsening upward sequence representing by grain size is most probably a prograding wave- and storm- influenced coast [6]. Furthermore, an evidence of good sorting from medium to coarse grain size is due to winnowing process during a prolonged storm-wave event at the foreshore.

\subsubsection{Facies Association 2 (FA 2): Upper Shoreface}

\section{(1) Description}

This facies association 2 (FA 2) comprises of thick, good sorting, fine to medium grain size, which lies in an outcrop at Tusan Beach. It is measured about 46 meter high vertically and 50 meter horizontally (Figure 2 (a) and (b)). The best exposure of this FA 2 is at Tusan Beach where their co-set of cross bedded is clearly exposed (Photo 2 (a)). Swaley cross stratified sandstone bed $(\mathrm{ScS})$ ranges in thickness with a various scale at Tusan Beach, Lambir Hills and Tanjung Lobang. This is because it shows a harmonic banding pattern with their linear convex expands in different sizes toward the bottom of sandstone bed (Photo 2 (b)). At Lambir Hills, small scale of cross bedded sandstone appear as swale in a middle part of bedding. Relationship between other facies can be seen in an alternation of hummocky cross stratified (HcS) which is related to FA 3's swale bedding. Trace fossils like, ophiomorpha sp and Thalassinoides sp are moderately abundant within the sandstone bed.

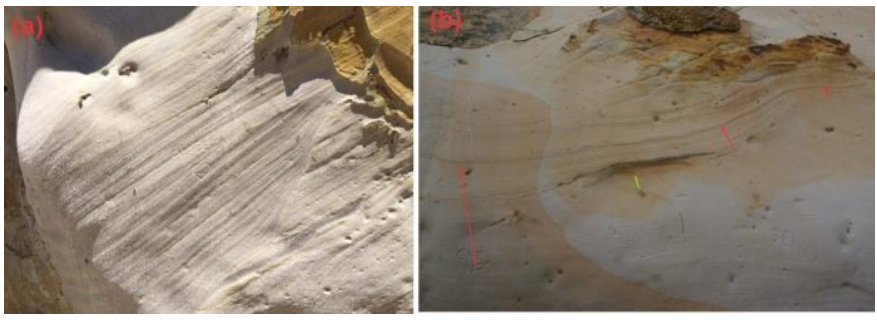

Photo 2: (a) Set of swaley cross stratified $(\mathrm{ScS})$ within thick sandstone bed. (b) The harmonic banding pattern of swaley cross stratified with their linear convex expanded in different size toward the bottom of sandstone bed.

\section{(2) Interpretation}

Existent of swaley cross stratified sandstone $(\mathrm{ScS})$ bed with thick and good sorting of grain size is a good indicator of upper shoreface environment Thick bedded sandstone with good sorting of grain size showed that, a high energy of winnowing process by transported current during deposition. A co-set of ScS occured due to storm event, where elliptical to circular scour-based are typically mix with flattening upward laminae [7] Various scale of ScS showed that occurred changing in current intensity in the upper shoreface environment during storm event. Transition of environment from FA 2 to FA 3 can be seen through changing in grain size where the medium grains change laterally to fine grain size. Moderately abundant of ophimorpha sp and Thalassinoides sp are illustrated as upper shoreface environment sandstone.

\subsubsection{Facies Association 3 (FA 3): Middle Shoreface}

\section{(1) Description}

This facies association consists of swaley and hummocky cross stratified facies (SHcS). One of the best outcrops exposed is at Lambir Hill, which is excellent exposure of alternate hummocky-swaley cross stratified sequence. However, it is exposed as small scale. The thickness of respective bed can be achieved approximately to $40 \mathrm{~cm}$ vertically. The hummocky cross stratified (HcS) is overlain by swaley cross stratified $(\mathrm{ScS})$ in similar bedding sequence (Photo 3). According to the outcrop exposed, it shows that the swaley cross bed is thicker than the hummocky cross bed, where swaley cross bed is sandstone dominated-interval. Futhermore, it is low scoured surface, consisting of moderately well- to well sorted medium grained size. On the other hand, FA 3 is less amalgamated and interbedded with mud. The heterolithic facies also occur in the lower part of sandstone bed. Intense bioturbation occur in sandstone bed including burrows and large group of ophiomorpha sp.

\section{(2) Interpretation}

The swaley and hummocky exist in similar sequence of bedding, are due to the combination of high density progressive current after deposition. Apart, high energy of storm will force sediment to create a mould (hummock-swale). According to a researcher, the presence of $\mathrm{HcS}$ in a ScS facies indicates high energy process and high frequent of episodic deposition [8]. As suggested by a previous researcher, this environment of deposition is dominated by incorporated of oscillatory and unidirectional current on shoreface while storm event [9]. Sedimentary facies showed that the $\mathrm{ScS}$ is formed first then continue by $\mathrm{HcS}$ is related to normal deposition in middle shoreface environment. The ScS is thicker than HcS because, net sediment from FA 2 is still active supplied to the lower part of shoreface area. The variety of grain sizes such as, fine to medium interval and moderate to well sorted grains are resulted from transition of high energy to lower energy event during deposition in a middle to lower shorface. Heterolithic bed occur in a few part of this facies association suggests that it may belongs to tidal influence during subtidal area. Intense of bioturbation with abundant of Ophiomorpha characterized lower shoreface sandstones. 


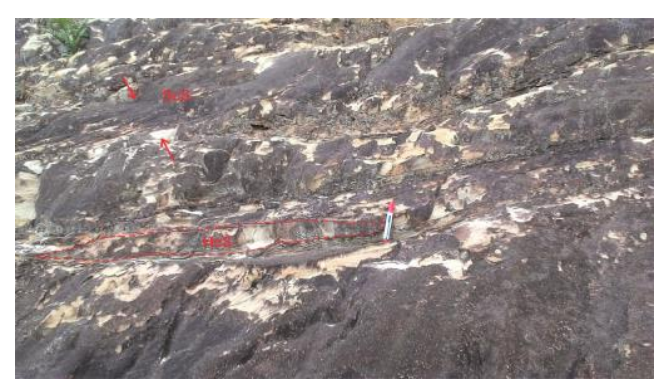

Photo 3: The hummocky cross stratified is overlaid by swaley cross stratified in one bed. Location is in Lambir Hill

4.2.1.4 Facies Association 4 (FA 4): Lower Shoreface

\section{(1) Description}

This facies association consists of HcS facies where it is varied upon its exposure at Tusan Beach and Lambir Hill regarding on facies characteristic. A set of cross bedded is referred to a series of hummock pattern in the bed (Figure 2 (a)). Basically the hummocky cross bedded is poorly exposed, where it is dominantly covered by heterolithic unit (Photo 4 (a) and (c)). At the Tusan Beach the HcS facies is thick cross bedded sandstone with moderately sorted grain size without showing coarsening upward sequence. The individual bed ranges from $10 \mathrm{~cm}$ to $30 \mathrm{~cm}$ thick (Photo 4 (b)). Meanwhile, at the Lambir Hills the facies is displayed as medium cross bedded sandstone interbedded with mud. The HcS typically scoured at the base, while at the upper part is undulating lamination with exposure of sand pit, less amalgamated bedding and sharp contact with overlying heterolithic mud. Little exposure of heterolithic mud can be seen as a mud laminae but consist of coal lense. Bioturbation is definitely moderate in a sandstone bed. Medium amount of burrows like ophiomorpha sp and thalasinoides sp lies in sandstone (Photo 4 (d)).

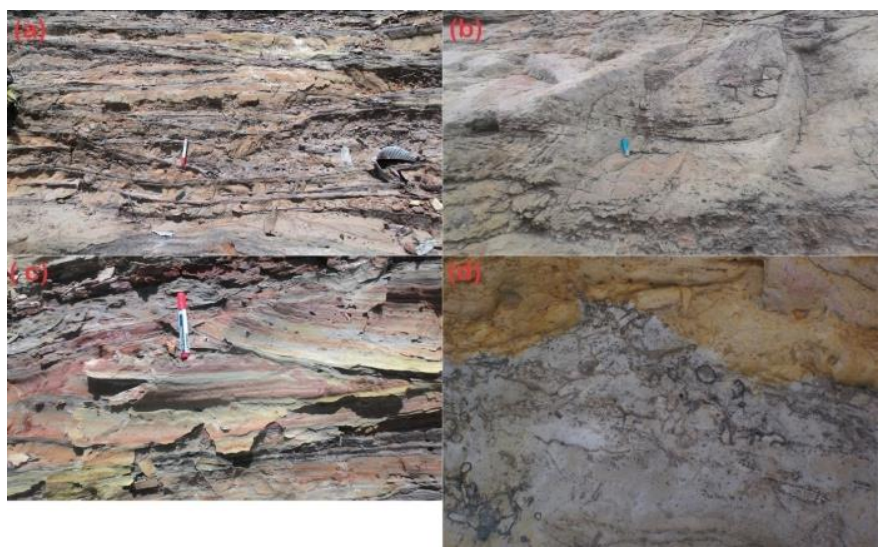

Photo 4: (a) and (c) The hummocky cross stratified (HcS) is poorly exposed and it is dominantly covered by heterolithic unit. (b) The HcS facies is thick cross bedded sandstone with moderately sorted grain size without showing coarsening upward sequence. Location in Tusan Beach. (d) Moderate burrows like ophiomorpha sp and thalasinoides sp lies in sandstone

\section{(2) Interpretation}

Poor existence of hummocky cross stratified interbedded with mud in a few part of outcrop is related to fair current activity during storm event. Apart, the process of sedimentation was slowing down toward the end of the basin and eventually brought to a settlement of sand and mud. The heterolithic bed occurs in the hummocky cross bed is indicated that the deposition is tide influenced regime. Moderately well sorted grain size was due to mixture of sediment during slow current activity. Evidence of scour at the base of sandstone bed was related to erosion of soft sediment surface during direct current flew through it. Furthermore, undulating hummocky lamination was produced by various activity of current and particular environment. As stated by a researcher, undulating feature in the hummocky was produced either by storm wave base or by storm of hurricane flow [10]. However, a previous study suggested that the undulating lamination can be yielded by oscillatory flow [11]. Moderate exposure of bioturbation like ophiomorpha sp and thalasinoides sp with complex burrow system is characterized as lower shoreface sandstone.

\subsection{Tide Dominated Regime}

Heterolithic Facies (He) is based on the variable of sand/shale percentages and internal sedimentary set ups from the outcrop. This facies is segregated into three heterolithic sub-facies, namely; flaser bedded sub-facies ( $\%$ sand $>\%$ mud), Wavy bedded sub-facies $(\%$ sand $=\%$ mud) and Lenticular bedded sub-facies ( $\%$ mud $>\%$ sand).

\subsubsection{Tidal Sand bar Facies Association (TSB)}

\subsubsection{Description}

This facies association is characterised as thick bedded sandstone with less amalgamated bed. TSB consists of herringbone cross stratified facies (Hrr), which is a major sedimentary structure exists in the sandstone bed. Hrr facies is obscured in a few places at the study area. However one of the outcrops exposed at Tusan beach is slightly good but in small scale. It ranges from 8 to $10 \mathrm{~cm}$ thick with co-set series of Hrr facies (Photo 5 (a)). Unfortunately they are hidden by intensive weathering process and dominantly covered by heterolitic unit, thus harder to differentiate clearly. Mud drape is clearly observed between cross bedded set and mostly lies in lower part of sandstone bed. This facies association can be seen as a linked with FA 1 in an upper part of the bedding. It is basically associated with FA 1 regarding on facies succession. Bioturbations like Ophiomorpha $\mathrm{sp}$, Thalassinoides sp. and Paleophycus sp. are highly diversified and more abundant in the tidal bar and has complex burrow system (Photo 5 (b)).

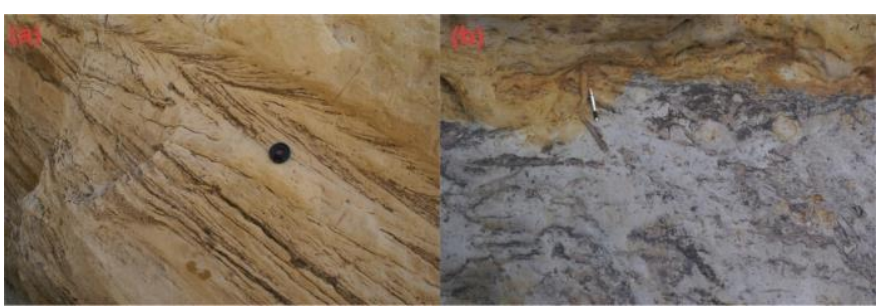

Photo 5: (a) Photo showing small scale of herringbone cross stratified sandstone bed (Hrr). (b) Bioturbation like Ophiomorpha sp, Thalassinoides sp. and Paleophycus sp. is high diversity and more abundant in tidal bar environment and has complex burrow system

\subsubsection{Interpretation}

Thick bedded sandstone with less herringbone cross bed was developed by strong wave during different flow of tide. Apart, herringbone with uncommon characteristic was due to tendency flow of ebb and flood tidal moving in different pathways, where the flood tide move upward and the ebb tide move downward to the other side. Mud drapes occurrence are a typical evidence for tidally influenced environment [12]. According to a researcher, mud drapes occurred within lamination of cross bed are due to deposition of lamina sand on the lee slope in the subaqueous dune during strong tidal event [13]. Clay material eventually fall out as suspension when tidal switched its direction, thus draped the subaqueous dune. Decrease of tidal range between meso- to inter-tidal contributed to thicker foreshore due to swash-backwash process. High diversity and more abundance of organisms are due to prone environmental conditions for living organism, progressively shifting substrates and overall high presentation potential [14]. Based on the description of facies association above, we interpreted this facies association as tidal sand bar.

\subsection{Tidal Sand Flat Facies Association (TSF)}

\section{(1) Description}

This lithofacies association consists of lithofacies (Ff) and lithofacies (Fw) Ff lithofacies is characterised by large amount of sandstone rather than mud with ratio; amount of sand is more than mud about $80 \%$ to $10 \%$ (Photo 6 (a)). The flaser-wavy bedded lithofacies is common in outcrops around Tusan Beach, Bakam road and Lambir Hills (Photo 6 (b)). Ff lithofacies displays like micro hummocky formed in the sandstone bed interbedded with thin mud. Typically this structure is irregular in size with undulating base. According to one outcrop at a Bakam road, the best exposure of this lithofacies recorded is about five meter vertically. Apart, Fw lithofacies is usually seen as interbedded straight to slightly wavy intercalations of millimetre to centimeter thick units of grey to bluish grey mud and light grey ripple cross-laminated sandy siltstone and fine sandstone, forming wavy-bedded facies. The laminated sands are typically ripple-laminated and mud-draped, generally irregular in shape and bipolar. Burrows and soft-sediment deformation structures, generally small-scale fill structures were found in several outcrops (Photo 6 (d)). Bioturbation relatively moderate compared to tidal sand bar with abundant of Ophiomorpha sp., Palaeophycus sp., skotlithos sp. and Thalassinoides sp (Photo 6 (c)) . 


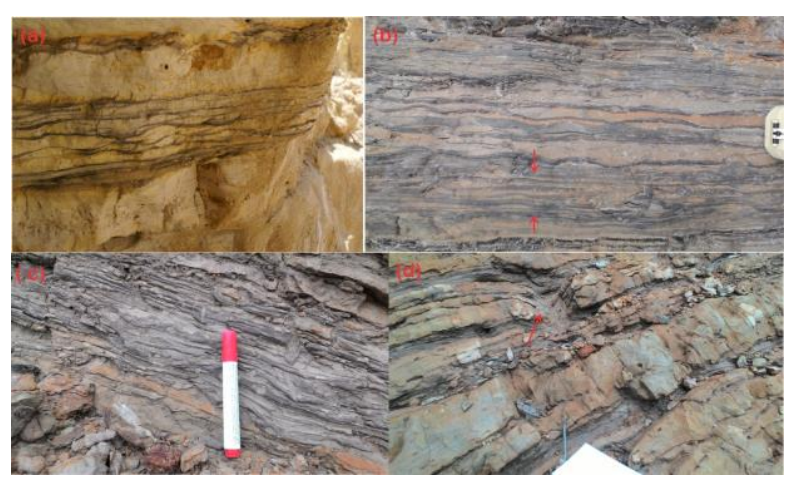

Photo 6: (a) Flaser structure display like micro hummocky formed in the sandstone bed interbedded with thin mud. Location in Tusan Beach. (b) Interbedded straight to slightly wavy intercalations (red arrow) of millimetre to centimeter thick units of grey to bluish grey mud and light grey ripple cross-laminated sandy siltstone and fine sandstone. (c) Bioturbation relatively moderate in tidal flat deposition. (d) Soft-sediment deformations structures, generally small-scale fill structures were found in several outcrops at Lambir Hill.

\subsubsection{Interpretation}

Exposure of flaser and wavy bedding is related to unidirectional flow of current in water due to decrease in water velocity. This is similar statement from Nichols and Ekwenye (2016), which is caused by migration of unidirectional current in water during deceleration of high velocity current. However, the ripples in this facies are generally irregular in shape and bipolar, suggesting that deposition under bidirectional nonuniform energy. According to a researcher, abundant of mud drapes within flaser bedding and ripple cross laminations give evidence of tidalinfluenced environment [15]. Furthermore, a study stated that mud drapes are typically one of the most distinctive features of tidal deposits and represent the fluctuation of a tide [16]. Heterolithic bedding like flaser and wavy bedding are basically natural evidence of a tidal-flat environment [17]. Moderately bioturbation explain that the velocity of current was slow and sufficient food for organism to grow. This facies association is interpreted as tidal sand flat.

\subsection{Subtidal Mud Flat Facies Association (SMF)}

\subsubsection{Description}

Tusan Beach

(a)

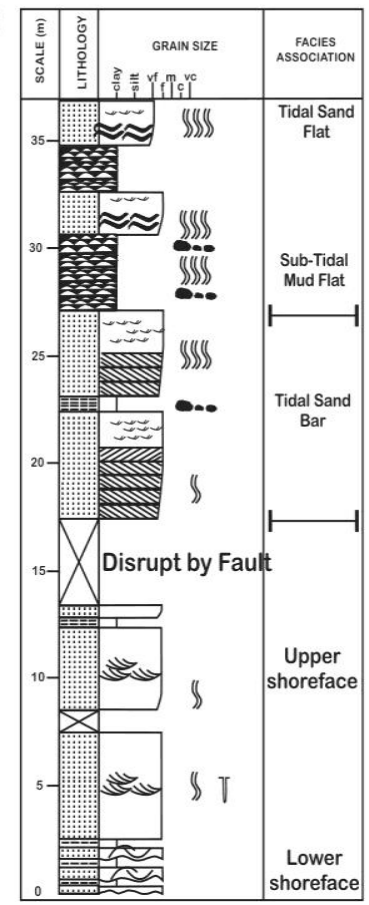

Sg. Nakat

(b)

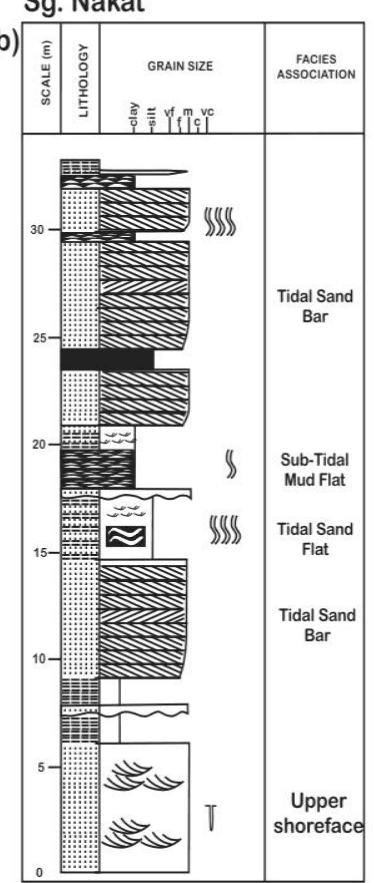

Lambir Hill

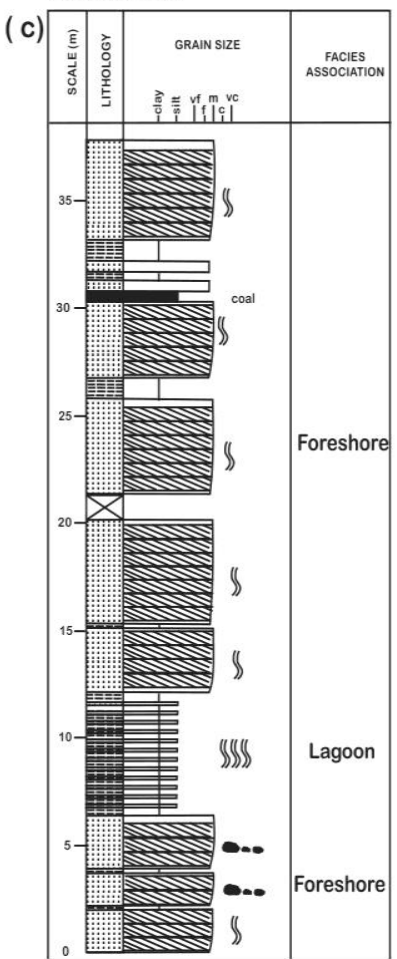

This facies association consists of Lenticular bedded facies which comprises of rhythmic to alternate layer of thin sand with clay (Figure 2 (a) and (b)). Best outcrop recorded is along Bakam Road to Tusan Beach approximately achieve 8 meter thick. SMF has colour from grey to bluish grey and many colours are dark (Photo 7 (a)). The lenticle internally shows micro cross-lamination with $2-4 \mathrm{~mm}$ solid ripples. The foreset laminae in vertically adjacent rippled lenses often reveal resisting dipdirections. Thin coal bed also occurs within mud and mostly covered large area around Tusan Beach. The process of bioturbation is rarely to quite low within heterolithic rock for example, burrows occur at several intervals within a few outcrops at Tusan Beach and Lambir Hill (Photo 7 (b)). Soft sediment deformation as well as micro-scale folds and flaws are apparent in several units of lenticular-bedding.

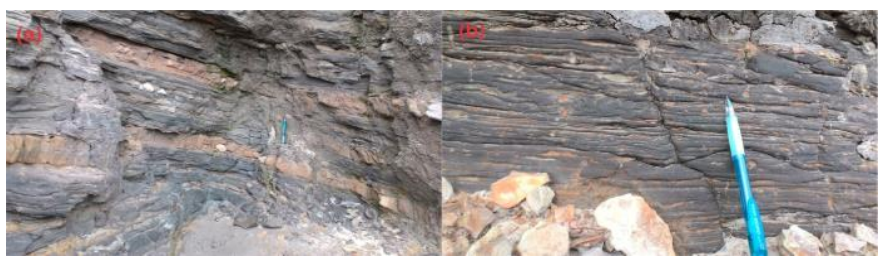

Photo 7: (a) Lenticular bedding consist almost 90\% mud rather than sand, representing subtidal flat environment. (b) Photo showing process of bioturbation is rarely to quite low within heterolithic rock

\subsubsection{Intepretation}

Existence of lenticular bedding is good evidence of sub-tidal mud flat. This is because, mud is heavily exposed rather than sand. As supported by a previous researcher that rhythmic layer of mud interpreted as a sub-tidal mud flat [18]. Alternation of thin-clay layers indicate cyclic process occur during tidal influence on inner estuarine sediments [19]. The fine grain size indicates slow current movement during deposition. According to a researcher, the silt layers represent traction deposition from ebb and flood tides, whereas the clay layers represent deposition from suspension during slack-water period [20]. The foreset laminae in vertically adjacent rippled lenses, indicate their deposition by current reversal. Burrow is rarely observe in this facies association, typically is related to high rate of sedimentation or low salinity of water to support burrowing organism.

Figure 2: (a) Diagram showing the vertical litholog of Tusan Beach representing wave to tidal facies association. (b) Diagram showing the vertical litholog analysis of Sg. Nakat, near to Lambir Hill, illustrated partition of wave-tide dominated environment. (c) Diagram showing the vertical litholog of Lambir Hill comprised of planar cross stratified representing foreshore environment. 


\section{ENVIRONMENTAL INTERPRETATION AND MODELLING}

Based on the observation from several locations around Tusan Beach to Lambir Hills, this study yielded numerous information in terms of; facies characteristics (as well as facies association), sedimentary structure diagnostic, lithology and bioturbation data. The result estimated that the environment record is divided into wave-dominated and tidal dominated regime. Basically wave-dominated area was estimated to have tidal range from $0-2 \mathrm{~m}$ to $2-4 \mathrm{~m}$ which classified as micro- to meso-tidal range process (Figure 3 (b)) [21]. Whereas, tide-dominated is $>4 \mathrm{~m}$ tidal range and ranged from meso to macrotidal.

\subsection{Evidence of Wave Dominated Deposition}

The wave dominated regime is dominated by estimation of $20 \%$ covered the whole study area (it is covered by three or four outcrops in the field and others are tidal deposit) and it ranges from lower shoreface (FA 4) to foreshore (FA 1) facies association. The hummocky-swalley cross stratified structure ( $\mathrm{ScS}$ and $\mathrm{HcS}$ ) discussed above is not too extensive displayed in the total outcrop. The exposure is either intermittent or obscure and sometime filled by the tidal deposit. This situation actually discussed by Selley (1970), according to low input of sediment from the land during stormy coasts [23]. Otherwise, exposure of planar cross stratified (PcS) at Lambir Hill interbedded with lagoon mud (see table 1.0) generally occured in high energy foreshore environment (zone of breaking waves and swash zone). By referring to the ternary diagram of a researcher (Figure 3 (a)) this research suggest that, the evidence of wave dominated regime exist in the Lambir Formation (swaley and hummocky cross stratified) is due to strong tidal currents influence on shoreface [24]. The evidence of tidal dominant in microtidal area is due to increase of tidal current and topographic construction.

\subsection{Evidence of Tidally Dominated Deposition}

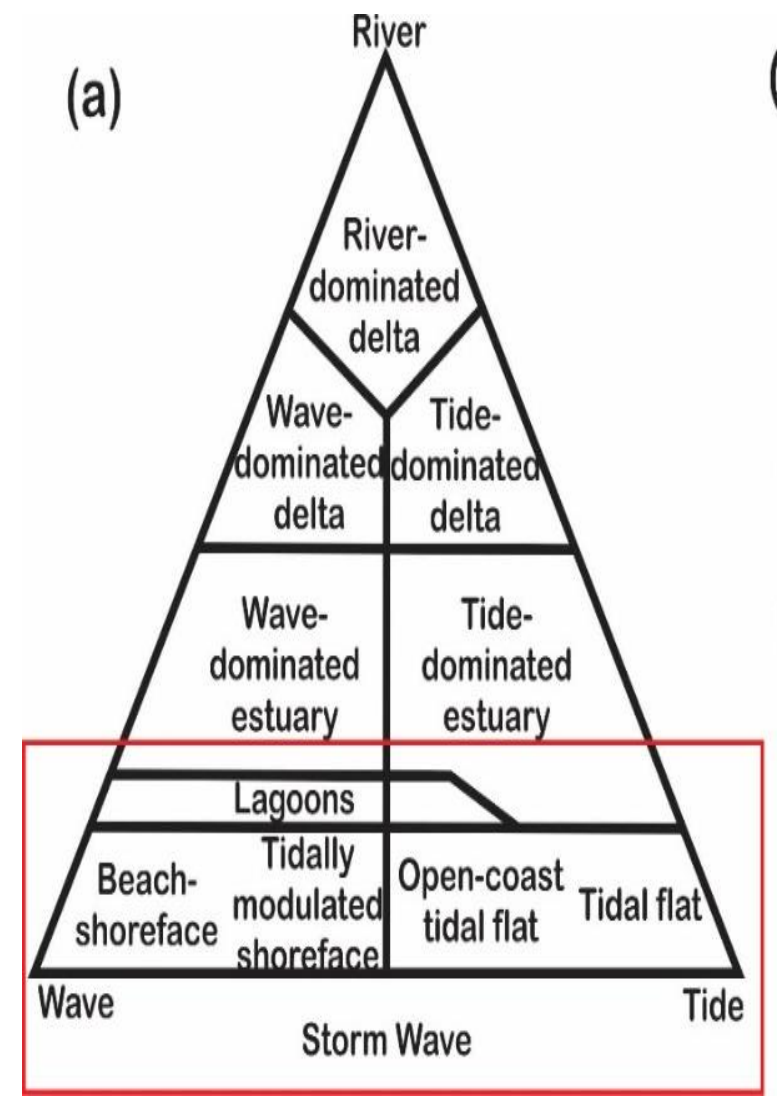

Tidal's facies analysis have yielded three facies associations attribute to environmental process, namely tidal sand bar (TSB), tidal sand flat (TSF) and subtidal mud flat (SMF). Tidal process of the Middle Miocene sedimentation in North West Borneo actually have been discussed by many researchers [25]. Some sedimentary structures exist in the Lambir Formation is related to tidal environment, such as herringbone cross bedding (bimodal) paleocurrent, rhythmic mud bedding, microlamination mud, mud drapes, reactivation surface, ripple lamination, flaser bedding, wavy bedding and lenticular bedding. Those are created according to fluctuation of flood and ebb current during tidal range effect. Environmental modelling is established according to facies analysis data. One of the parameter used is sedimentary structure diagnostic. We assumed that the occurrence of herringbone cross stratified beds in the study area was related to tidal sand bar deposit (TSB). It was resulted from a tidal current in different direction for a period of time. This sedimentary structure only exposed at Tusan Beach and Sg. Nakat areas, meaning that, only that area are covered by tidal sandy deposit. Besides, herringbone structure displayed as a diagnostic features of transition tidal to river environment. Dominant exposure of heterolithic bedding like flaser and wavy bedding suggested as deposited in tidal sand flat (TSF) environment where velocity of current decrease and then create irregular ripples under bidirectional non-uniform energy. Furthermore, mud drapes occur within cross laminated suggest a tidal influenced regime and fluctuation of tide. The evidence of lenticular bedding in the study area, is related to prdominanace of mud and silty sand. The occurrence of thick mud rather than sand is representing subtidal mud flat (SMF) deposition. SMF is characterized as slow current movement of particle during slack water period. Furthermore, rhythmic layer of mud indicate cyclic process occured during tidal influence on inner estuarine sediments. By referring ternary diagram (figure 3 (a)), the environment of deposition was largely influenced by tide dominated regimes. (b)

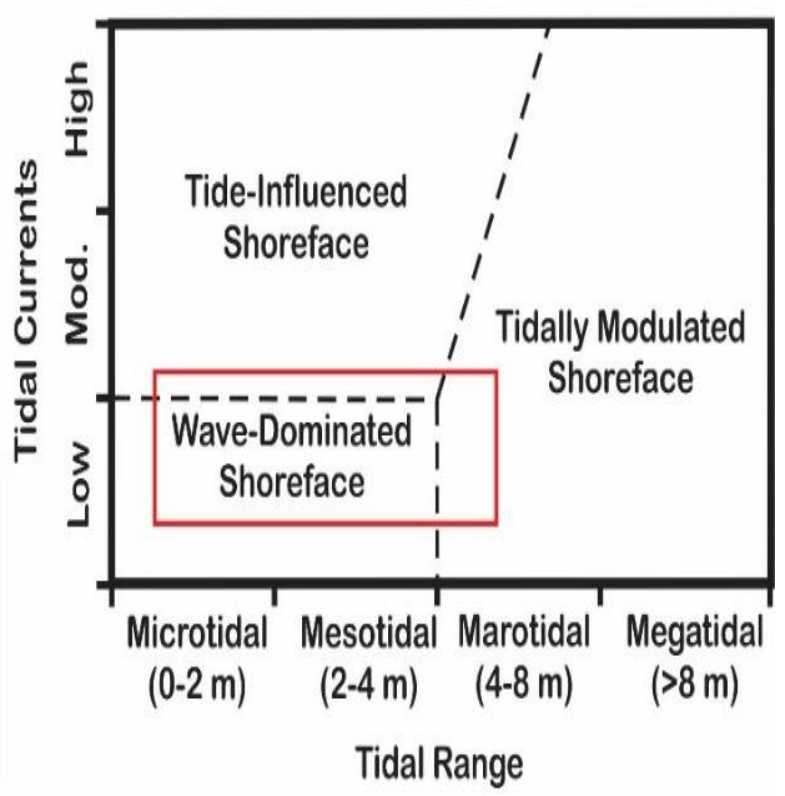

Figure 3: (a) Ternary diagram modified after Dalrymple et al. (1992) and Dashtgard et al. (2009) is used to relate the evidence of wave-tides dominated area of Lambir Formation. (b) The wave-dominated area is estimated to have tidal range from $0-2 \mathrm{~m}$ to $2-4 \mathrm{~m}$ which classified as micro- to meso-tidal range process (Johnson and Baldwin, 1996).

Moderate to low bioturbation with low intensity occurrence of ophiomorpha sp., thalasinoides sp. and skotlithos sp. suggest that deposition was in a high energy, inter-tidal flat environment then a researcher determine that condition to tide dominated shoreface environment. Most of trace fossil assemblage recorded by previous study that related to depositional environment was due to moderate wave and tidal energy. This is because a limited fetch in the South China Sea the wave energy of North West Borneo margin has been reduced [26]. Based on observation from wave dominated regimes in the Lambir Formation, it shows that a similar variation on higher energy equivalents. While, in tide dominated regimes, it shows inconsistent variation from low to higher energy settings.

According to concrete evidences discussed above, the environment of deposition is suggested ranging from lagoon, tidal flat and barrier island, however it may be detached separately from fluvial (Figure 4) due to absent of sedimentary structure related to fluvial deposit in the field. 


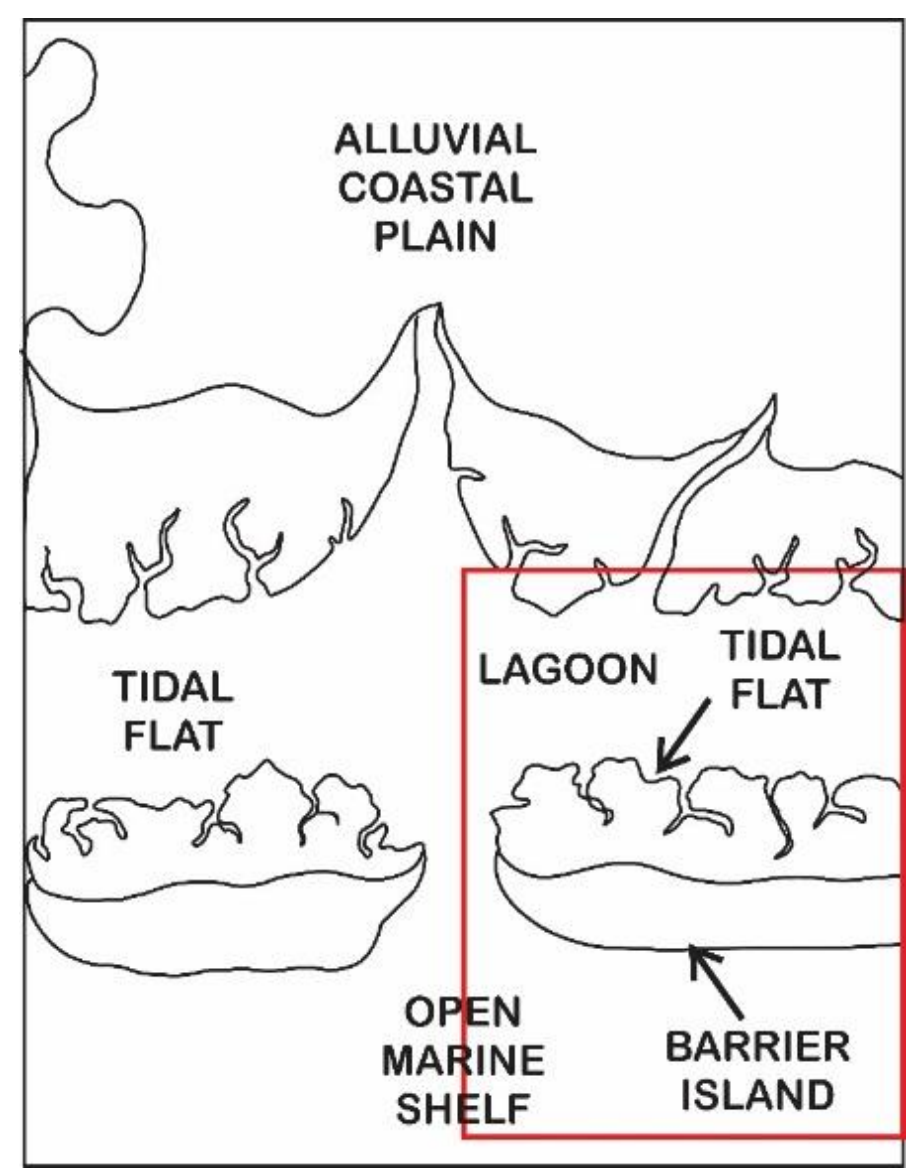

Figure 4: The environmental model of deposition is suggested ranging the area from lagoon, tidal flat and Barrier Island but it may be detached separately from fluvial system. Adaptation from Selley (1978)

\section{CONCLUSION}

As a conclusion, lot of favourable sedimentological data collected in the field as discussed above in the Middle Miocene Lambir Formation. The result showed the presence of wave-tide dominated regime. On the other hand, the exposure of wave dominated regime is small and limited rather than tidal dominated regime. However, wave dominated structure also exist in tide dominated area. The evidence of wave dominated regime occur within tidal area representing a coastal barrier shoreface setting, where the sediment was accumulated, due to tidal range, variable of wave energy, amount of sediment supply and sea-level trends. Apart, tidal flat was naturally associated with barrier island where mud was transported and deposited by tides. The evidence of tidal flat can be seen through heterolithic structures formed like flaser, wavy and lenticular bedding.

\section{REFERENCES}

[1] Wannier, M., Lesslar, P., Lee, C., Raven, H., Sorkhabi, R., Ibrahim, A., 2011. Geological Excursions Around Miri, Sarawak. EcoMedia Software, 279.

[2] Banda, R.M., Honza, E. 1997. Miocene stratigraphy of northwest Borneo Basin. Geol. Soc Bull (40), 1-11.

[3] Dashtgard, S.E., Gingras, M.K., MacEachern, J.A. 2009. Tidally modulated shorefaces. Journal of Sedimentary Research, (79), 793-807.

[4] Liechti, P., Roe, F.N., Haile, N.S., Kirk, H.J.C. 1960. The geology of Sarawak, Brunei and the Western part of North Borneo. British Borneo Geological Survey, Bulletin, 3.

[5] Hutchison, C.S. 2005. Geology of Northwest Borneo, Sarawak, Brunei and Sabah. Elsevier.

[6] Plint, A.G. 2010. Wave-and storm-dominated shoreline and shallowmarine systems. In Facies Models 4, edited by James, N.P. \& Dalrymple, R.W. Geological Society of Canada, St. John's, 167-200.

[7] Leckie, D.A., Walker, R.G. 1982. Storm- and tide-dominated shorelines in the Cretaceous Moosebar-lower Gates interval - outcrop equivalents of deep basin gas trap in western Canada. American Association of Petroleum Geologists Bulletin, 66, 138-157.
[8] Vakarelov, B.K., Ainsworth, R.B., MacEachern, J. 2012. Recognition of wave dominated, tide-influenced shoreline systems in the rock record: Variations from a microtidal shoreline model. Elsevier, 23-41.

[9] Swift, D.J.P., Figueiredo, A.R., Freeland, G.L., Oertel, G.F. 1983 Hummocky cross stratification and megaripples: a geologic double standard? Journal of Sedimentary Petrology, (53), 1295-1317.

[10] Hamblin, A.P., Walker, R.G., 1979. Storm-dominated shallow marine deposits-the ferine-kootenay (jurassic) transition, southern rocky mountains. Canadian Journal of Earth Sciences,16, 1673-1690.

[11] Southard, J.B., Lambie, J.M., Federico, D.C., Pile, H.T., Weidmam, C.R. 1990. Experiments on bed configurations in fine sands under bidirectional, purely oscillatory flow, and the origin of hummocky crossstratification. Jour. Sed. Petr., (60), 1-17.

[12] Nichols, G. 2009. Sedimentology and Stratigraphy. 2nd Edition Oxford. 419 .

[13] Dalrymple, R.W., Zaitlin, B.A., Boyd, R. 1992. Estuarine facies models conceptual basis and stratigraphic implications. Journal of Sedimentary Petrology, (62), 1130-1146.

[14] Howard, J.D., Frey, R.W., 1984. Characteristic trace fossils in nearshore to offshore sequences, Upper Cretaceous of east-central Utah. Canadian Journal of Earth Sciences, (21), 200-219.

[15] Dalrymple, R.W., Choi, K., 2007. Morphologic and facies trends through the fluvial-marine transition in tide-dominated depositional systems: a schematic framework for environmental and sequencestratigraphic interpretation. Earth-Science Reviews, 81, 135-174.

[16] Reading, H.G. 2009. Sedimentary environments; Process, facies and stratigraphy. John Wiley and Sons.

[17] Reineck, H.E., Wunderlic, F. 1968. Classification and origin of flaser and lenticular bedding. Sedimentology, 11, 99-104.

[18] Nio, S.D., Yang C.S. 1991. Diagnostic attributes of clastic tida deposits: a review. In Smith D.G., Reinson G.E., Zaitlin B.A, Rahmani R.A (eds.), Clastic tidal sedimentology . Canadian Society of Petroleum 


\section{Geologists, Memoir, 16, 3-28.}

[19] Kuecher, G.J., Woodland, B.G., Broadhurst, F.M. 1990. Evidence of deposition from individual tides and of tidal cycles from the Francis Creek Shale (host rock to the Mazon Creek biota), Westphalian D (Pennsylvanian), northeastern Illinois: Sedimentary Geology, 68, 211221.

[20] Shanmugam, G., Poffenberger, M., Toro Álava, J. 2000. TideDominated Estuarine Facies in the Hollin and Napo ("T" and " $U$ ") Formations (Cretaceous), Sacha Field, Oriente Basin, Ecuador. AAPG Bulletin, V. 84(5), 652-682.

[21] Johnson, H.D., Baldwin, C.T. 1996. Shallow siliciclastic seas, in Reading, H.G., ed., Sedimentary Environments; Processes, Facies and Stratigraphy, Third Edition, Cambridge, Massachusetts, Blackwell Science, 688.

[22] Selley, R.C. 1978. Ancient Sedimentary Environments. 2nd Edition.
Chapman Hall, 287.

[23] Dashgart, S.E., MacEachern, J.A., Frey, S.E., Gingras, M.K., 2012. Tidal effects on the shoreface: Towards a conceptual framework. Sedimentary Geology, (279), 42-61.

[24] Hassan, M.H.A., Yeow, B.S., Lee, C.P., Abdul Hadi A.R. 2013. Facies Analysis of the Uppermost Kubang Pasu Formation, Perlis: A Wave-and Storm-influenced Coastal Depositional System Sains Malaysiana, 42(8), 1091-1100.

[25] Ekwenye, O.C., Nichols, G., 2016. Depositional facies and ichnology of a tidally influence coastal plain deposit: The Ogwashi Formation, Niger Delta Basin. Arabian Journal of Geosciences, (9), 700.

[26] Mat Fiah, N., Lambiase, J.J. 2014. Ichnology of shallow marine clastic facies in the Belait Formation, Brunei Darussalam. Search Results Web results Bulletin of the Geological Society of Malaysia 60, 55-63. 